\title{
Self-Encapsulation of Biomacromolecule Drugs in Porous Microscaffolds with Aqueous Two-Phase Systems
}

\author{
Jian Kang ${ }^{\dagger}$, Yunpeng Cai ${ }^{\dagger}$, Ziwei Wu, Siyi Wang and Wei-En Yuan * \\ Engineering Research Center of Cell \& Therapeutic Antibody, Ministry of Education, School of Pharmacy, \\ Shanghai Jiao Tong University, Shanghai 200240, China; jkang@sjtu.edu.cn (J.K.); \\ cai_yunpeng@wuxiapptec.com (Y.C.); vero_shero@sjtu.edu.cn (Z.W.); wangnima@sjtu.edu.cn (S.W.) \\ * Correspondence: yuanweien@sjtu.edu.cn \\ + These authors contribute equally to this paper.
}

check for

updates

Citation: Kang, J.; Cai, Y.; Wu, Z.; Wang, S.; Yuan, W.-E.

Self-Encapsulation of

Biomacromolecule Drugs in Porous

Microscaffolds with Aqueous

Two-Phase Systems. Pharmaceutics 2021, 13, 426. https://doi.org/ 10.3390/pharmaceutics13030426

Academic Editors: Marta

González-Álvarez and Viviana Pinto Ribeiro

Received: 6 January 2021

Accepted: 15 March 2021

Published: 22 March 2021

Publisher's Note: MDPI stays neutral with regard to jurisdictional claims in published maps and institutional affiliations.

Copyright: (c) 2021 by the authors. Licensee MDPI, Basel, Switzerland. This article is an open access article distributed under the terms and conditions of the Creative Commons Attribution (CC BY) license (https:/ / creativecommons.org/licenses/by/ $4.0 /)$.

\begin{abstract}
At present, the most commonly used methods of microencapsulation of protein drugs such as spray drying, multiple emulsification, and phase separation, can easily cause the problem of protein instability, which leads to low bioavailability and uncontrolled release of protein drugs. Herein, a novel method to encapsulate protein drugs into porous microscaffolds effectively and stably was described. Ammonium hydrogen carbonate $\left(\mathrm{NH}_{4} \mathrm{HCO}_{3}\right)$ was employed to prepare porous microscaffolds. $\alpha$-Amylase was encapsulated into the porous microscaffolds without denaturing conditions by an aqueous two-phase system (PEG/Sulfate). The pores were closed by heating above the glass transition temperature to achieve a sustained release of microscaffolds. The pore-closed microscaffolds were characterized and released in vitro. The integrity and activity of protein drugs were investigated to verify that this method was friendly to protein drugs. Results showed that the pores were successfully closed and a high loading amount of $9.67 \pm 6.28 \%(w / w)$ was achieved. The pore-closed microscaffolds released more than two weeks without initial burst, and a high relative activity (92\% compared with native one) of protein demonstrated the feasibility of this method for protein drug encapsulation and delivery.
\end{abstract}

Keywords: self-healing; porous microscaffolds; aqueous two-phase system; biomacromolecule drugs; closed pores

\section{Introduction}

Biodegradable polymeric microparticles/microscaffolds mainly based on poly (D, L-lactic-co-glycolic acid) (PLGA) have been extensively studied as an injectable sustained release depot for protein delivery over the decades [1]. However, the most commonly used methods of microencapsulation of protein drugs are spray drying, multiple emulsion, and phase separation, which can introduce organic solvent-water interfaces, shear induced stress during emulsification, resulting in structure unfold, aggregation, and denaturation of proteins [2-4]. Protein instability leads to low bioavailability and uncontrolled release of protein drugs loaded microparticles/microscaffolds, which makes protein stability an urgent problem.

To address the stability issue, some researchers have turned to porous microparticles/microscaffolds, which have a high capacity for protein loading due to its porous structure [5]. Whitely M. et al. found that high protein loading efficiencies were achieved in porous microspheres. Although there is a short period of explosive release, the protein sustained released with minimal burst release [6]. Protein is encapsulated into porous microparticles/microscaffolds to avoid the problems caused by traditional preparation methods. After the protein is loaded, the pores of the particles are closed to form a sustained release depot.

Next, the question turned into how to encapsulate the protein and close the pores. To close the pores, heating to glass transition temperature (Tg) or above can trigger a "self- 
healing" process based on the mobility of the polymer chains. The mechanism includes polymer-chain inter-diffusion driven by minimization of the energetically unfavorable interfacial area and/or transfer of potential energy stored in the defect [7]. Hence, the loading efficiency is usually low without the driving force, which drives the protein into the pores. Desai and Schwendeman used $\mathrm{Al}(\mathrm{OH})_{3}$ as an antigenic adjuvant, increased the loading amount to about $1.3 \%(w / w)$, and heated it in water to close the pores [8]. However, the employment of an adjuvant cannot be regarded as a potent strategy to increase the loading amount in porous microparticles. Kim et al. used ethanol vapor in a fluidized bed to close the pores and achieved a high loading of $3.1 \pm 0.1 \%(w / w)$ of human growth hormone [9]. However, the exposure to organic solvent remains a question.

Herein, we describe a loading strategy with an aqueous two-phase system (ATPS), greatly increasing the loading amount and avoiding any factor to denature the proteins. ATPS is available in several combinations such as two polymers, one polymer, and one salt or two salts, which are low cost and high efficiency and have been used for decades in biotechnology applications as non-denaturating and initial separation media [10-14]. One of the most well-known ATPS forming combinations is poly(ethylene glycol) (PEG) and salt (such as phosphate, sulfate, and citrate), since the salt will capture a large amount of the water present. It is well understood that hydrophilic macromolecules, like proteins, generally cannot be distributed or diffused in hydrophobic polymer phases [15]. In this aqueous two-phase system, proteins will partition to the top, less polar, and more hydrophilic phase, usually PEG $[16,17]$. Thus, proteins can be encapsulated into porous microparticles/microscaffolds if it has a high partition coefficient in a phase that can be fixed in microparticles. Additionally, the distribution of biological macromolecules in ATPS is influenced by various factors such as their charge, molecular weight, concentration, and ionic composition of the medium $[18,19]$.

\section{Materials and Methods}

\subsection{Materials}

PLGA 2A (lactide/glycolide = 50/50, MW: 12,000) was purchased from Surmodic Pharmaceuticals, Inc., Birmingham, AL, USA. Bovine serum albumin (BSA) (MW: 66,446 KDa), $\alpha$-amylase (MW: 97,000), dinitrosalicylic acid and PEG4000 were purchased from SigmaAldrich (St. Louis, $\mathrm{MO}, \mathrm{USA})$. Ammonium hydrogen carbonate $\left(\mathrm{NH}_{4} \mathrm{HCO}_{3}\right)$, ammonium sulfate, trehalose, phenol, and other reagents were purchased from Sinopharm Chemical Reagent Co. Ltd. (Shanghai, China), analytically pure.

\subsection{Methods}

\subsubsection{Partition of Protein Drugs in the Aqueous Two-Phase System (ATPS)}

An aqueous two-phase system was prepared based on ammonium sulfate $(20 \% w / w)$ and PEG4000 $(10 \% w / w)$, with sodium chloride to adjust the partition. The protein solution with the concentration of $1 \mathrm{mg} / \mathrm{mL}$ was added, and the homogeneous protein solution was obtained by vortexing. The system was divided into two layers after standing for $1 \mathrm{~h}$, and samples from the upper and lower phase were assayed for protein concentration. Two systems and two proteins were investigated, along with the influence of sodium chloride concentration. One system was PEG/phosphate, using potassium dihydrogen phosphate and sodium hydroxide to adjust the $\mathrm{pH}$ to 7.0. The other was the PEG/sulfate system, using ammonium sulfate and PEG. BSA and $\alpha$-amylase were chosen as the model proteins.

The protein concentration was determined by the bicinchoninic acid (BCA) method and standard curve was used for each protein [20]. After mixing with the working solution and incubating at $37^{\circ} \mathrm{C}$ for $2 \mathrm{~h}$, the absorbance was measured at a wavelength of $562 \mathrm{~nm}$. The detection range of protein concentration was $0.5-200 \mu \mathrm{g} / \mathrm{mL}$. Ammonium sulfate and potassium phosphate could interfere with the binding of the dye Coomassie Blue G-250, resulting in a lower absorbance. In contrast, PEG elevated the absorbance slightly. Thus, the standard curve should add the same amount of PEG and salt to minimize the error (PEG: 0-200 $\mu \mathrm{g} / \mathrm{mL}$; salt: $40 \mu \mathrm{g} / \mathrm{mL}$ ). 


\subsubsection{Preparation of Porous Microscaffolds}

Porous microparticles/microscaffolds were prepared by solvent evaporation degradation of sodium ammonium hydroxide [21]. PLGA was dissolved in dichloromethane to form a $15 \%(w / w)$ solution and 10\% $(w / w)$ PEG4000 was added. $\mathrm{NH}_{4} \mathrm{HCO}_{3}$ was dissolved in purified water, and mixed with the PLGA solution at a volume ratio of 1:5. This primary emulsion was immediately homogenized at the speed of 10,000 rpm for $1 \mathrm{~min}$, and quickly transferred into $20 \mathrm{~mL} \mathrm{1 \%} \mathrm{PVA} \mathrm{and} \mathrm{10 \%} \mathrm{PEG} \mathrm{solution} \mathrm{to} \mathrm{form} \mathrm{microparticles} \mathrm{by} \mathrm{stirring}$ at a rate of $300 \mathrm{rpm}$ for $1 \mathrm{~min}$. Then, the suspension with microscaffolds was transferred into a bulky water phase with $10 \%$ PEG. After gently stirring for $2 \mathrm{~h}$, microscaffolds were collected by centrifugation and lyophilized in a freeze drier.

\subsubsection{Characterization of Porous Microscaffolds}

The surface morphology of porous microscaffolds was observed by a scanning electronic microscope (SEM, Philips 535 M). Samples were coated with gold. Photographs of porous microscaffolds and pore closed microscaffolds were taken.

The particle size of microscaffolds was measured by a particle size analyzer (Malvern Mastersizer 2000, Malvern, UK) using a refractive index of 1.4, an absorption rate of 0.001, and water as the medium.

The glass transition temperature of porous microscaffolds was measured by a differential scanning calorimeter (Mettler Toledo ${ }^{\circledR}$ DSC 1, Greifensee, Switzerland). Microscaffold samples were sealed in aluminum hermetic pans and thermograms were determined by heating from $20^{\circ} \mathrm{C}$ to $100{ }^{\circ} \mathrm{C}$ at a rate of $5^{\circ} \mathrm{C} / \mathrm{min}$ under a nitrogen atmosphere.

\subsubsection{Protein Drug Loading and Pore-Closing Process}

To encapsulate the protein drug into blank porous microscaffolds, $15 \mathrm{mg}$ of microscaffolds were accurately weighed and dispersed in a solution containing PEG/sulfate system and protein drug $(1 \mathrm{mg} / \mathrm{mL})$. The suspension was incubated for $24 \mathrm{~h}$ in a shaker at $25^{\circ} \mathrm{C}$ for protein drug loading, and another $24 \mathrm{~h}$ at $42{ }^{\circ} \mathrm{C}$ for pore closing [8]. Trehalose $(1 \% \mathrm{w} / \mathrm{v})$ was added to stabilize the protein drug. After incubation, microscaffolds were collected, washed three times with distilled water and lyophilized for further investigation.

\subsubsection{Porosity of Microscaffolds}

The porosity of the samples was measured by thee nitrogen adsorption-desorption test at $-196{ }^{\circ} \mathrm{C}$ using an AUTOSORB-IQ3 (Shanghai, China) specific surface area and porosity analyzer. First, the prepared blank microscaffolds and pore closed microscaffolds were degassing in a vacuum at $25^{\circ} \mathrm{C}$ for $6 \mathrm{~h}$, and then nitrogen adsorption was measured. Finally, nitrogen desorption experiments were carried out at the saturated temperature of liquid nitrogen. The multi-point Brunauer-Emmett-Teller (mBET) theory was used to calculate the surface area, and the average pore diameter was calculated using the Barrett-Joyner-Halenda (BJH) model [22,23].

\subsubsection{Determination of Loading Efficiency}

Ten mg microscaffolds were accurately weighed, dissolved in $2 \mathrm{~mL}$ acetonitrile, and centrifuged at $8000 \mathrm{rpm}$ for $5 \mathrm{~min}$. The supernatant was discarded and replenished with the same amount of acetonitrile. This process was repeated three times and then the residual solvent was volatized. The precipitated protein drug was re-dissolved in $0.8 \mathrm{~mL}$ PBS for the BCA assay.

\subsubsection{In Vitro Release}

Both porous and pore-closed microscaffolds were accurately weighed and dispersed in $1 \mathrm{~mL}$ PBS, and then incubated at $37^{\circ} \mathrm{C}$ in a shaker at a rate of $100 \mathrm{rpm}$. The supernatant was collected at a certain interval $(1,2,4,7,10,14 \mathrm{~d})$, the amount of protein drug was determined and fresh medium was added. After the release period, the residual microscaffolds were 
freeze-dried and the protein drug content was determined according to the same method as in Section 2.2.6.

\subsubsection{Integrity of Protein Drug}

Size exclusion chromatography (SEC) was performed to investigate the structural integrity of $\alpha$-amylase (column: TSK gel 2000 SW; mobile phase: phosphate buffer solution $\mathrm{pH} 7.4$; flow rate: $1 \mathrm{~mL} / \mathrm{min}$; wavelength: $214 \mathrm{~nm}$; sample volume: $20 \mu \mathrm{L}$ ).

The detection of the circular dichromatic spectrum (CD spectra) was carried out on the JASCO J-815 circular dichromatic spectrometer (JASCO, Japan Spectral Co. Ltd., Tkoyo, Japan). The natural $\alpha$-amylase and the prepared pore-closed microparticle were dispersed into water. The detection of circular dichromatic spectrum in the far ultraviolet region of $190 \sim 260 \mathrm{~nm}$, data pitch was $0.2 \mathrm{~nm}$, bandwidth was $2 \mathrm{~nm}$, and the scanning speed was $100 \mathrm{~nm} / \mathrm{min}$.

\subsubsection{Activity of $\alpha$-Amylase}

The activity of $\alpha$-amylase was determined by the dinitrosalicylic acid solution (DNS) method [24,25]. To prepare the DNS reagent, $10.6 \mathrm{~g}$ 3,5-dinitrosalicylic acid was dissolved in $500 \mathrm{~mL}$ distilled water in oil bath at $48{ }^{\circ} \mathrm{C}$, then $19.8 \mathrm{~g}$ sodium hydroxide solution was added slowly with stirring. A total of $306 \mathrm{~g}$ Rochelle salts (sodium potassium tartrate), $7.6 \mathrm{~mL}$ phenol (melt at $50^{\circ} \mathrm{C}$ ), and $8.3 \mathrm{~g}$ sodium metabisulfite were added into the solution. When all the components had dissolved, water was added to a total volume of $1416 \mathrm{~mL}$, then it was transferred into an amber bottle and stored for one week before use. A citric buffer ( $\mathrm{pH}$ 6.0) was prepared with $45.3 \mathrm{~g}$ sodium phosphate dodecahydrate and $7.74 \mathrm{~g}$ citrate acid with a total volume of $1000 \mathrm{~mL}$.

Different amounts of glucose were dissolved in $0.4 \mathrm{~mL}$ distilled water and mixed with $0.8 \mathrm{~mL}$ DNS. The mixture was incubated in a boiling water bath for $10 \mathrm{~min}$, and quickly cooled down to room temperature with cold water. Then, the absorbance at $540 \mathrm{~nm}$ was obtained to get a standard glucose curve. Similarly, $0.35 \mathrm{~mL} 1 \%(w / v)$ soluble starch solution was made with citric buffer, and mixed with $0.05 \mathrm{~mL} \alpha$-amylase solution. The mixture was incubated in an oil bath at $60{ }^{\circ} \mathrm{C}$ for $5 \mathrm{~min}$, then $0.8 \mathrm{~mL}$ DNS was added quickly to end the reaction and transferred to a boiling water bath for $5 \mathrm{~min}$. The absorbance was read and the amount of hydrolyzed glucose was calculated according to the standard curve.

\subsection{Statistical Analysis}

All experiment tests were repeated five times and data were shown as mean \pm standard deviation. $p<0.05$ was regarded as significant using GraphPad Prism 7 software (GraphPad Prism, Inc., CA, USA). Significant differences were evaluated using two-tailed t test between two groups for in vitro assays.

\section{Results and Discussion}

\subsection{Investigation on Aqueous Two-Phase Systems and Protein Drugs}

Aqueous two-phase systems were investigated to decide what kind of protein drugs have the potential to be partitioned into the porous microscaffolds. A protein drug that tends to distribute in the PEG phase needs to be picked out first. The sulfate and phosphate could lower the absorbance greatly due to their combination with copper ions, the chromogenic agent in the BCA method. In the ATPS, the two phases did not separate completely in fact, but each phase partially contained the other. The uncertainty of salt concentration made it difficult to determine the actual protein drug concentration in the PEG phase, even when the standard curve was corrected with the corresponding salt. Sodium chloride was added to adjust the distribution. The mechanism was that sodium ions and chloride ions had a concentration difference between the two phases, resulting in a potential difference. The partition coefficient $K$ of a biomolecule varies exponentially with the electrochemical potential difference between the phases and the net charge of the partitioned biomolecule (Table 1) [26-28]. 
Table 1. Partition coefficient (Log K) of different aqueous two-phase systems (ATPSs) and protein drugs. $\mathrm{K}=$ protein drug concentration in upper poly(ethylene glycol) (PEG) phase/concentration in lower salt phase.

\begin{tabular}{|c|c|c|c|c|}
\hline Formulation & ATPS & $\mathrm{NaCl}(w / v)$ & $\begin{array}{c}\text { Protein } \\
(1 \mathrm{mg} / \mathrm{mL})\end{array}$ & $\log K$ \\
\hline 1 & PEG4000/potassium phosphate (15\%: 10\%) & 0 & $\alpha$-amylase & -0.45 \\
\hline 2 & PEG4000/potassium phosphate (15\%: 10\%) & $0.8 \%$ & $\alpha$-amylase & -0.09 \\
\hline 3 & PEG4000/potassium phosphate (15\%: 10\%) & $1.2 \%$ & $\alpha$-amylase & -0.21 \\
\hline 4 & PEG4000/ammonium sulfate (15\%: 20\%) & 0 & $\alpha$-amylase & 0.30 \\
\hline 5 & PEG4000/ammonium sulfate (15\%: 20\%) & $0.8 \%$ & $\alpha$-amylase & 0.24 \\
\hline 6 & PEG4000/ammonium sulfate (15\%: $20 \%)$ & $1.2 \%$ & $\alpha$-amylase & 0.29 \\
\hline 7 & PEG4000/ammonium sulfate (15\%: 20\%) & 0 & BSA & -0.71 \\
\hline 8 & PEG4000/ammonium sulfate (15\%: 20\%) & $0.8 \%$ & BSA & -0.69 \\
\hline 9 & PEG4000/ammonium sulfate (15\%: 20\%) & $1.2 \%$ & BSA & -0.69 \\
\hline
\end{tabular}

$\alpha$-amylase was brown in solution, thus can be distinguished directly in the ATPS. Figure 1A shows the PEG/phosphate system (formulation 2) with no significant difference between the upper and lower phases. Figure 1B showed the PEG/sulfate system (formulation 2). It can be clearly seen that the upper PEG phase was darker, indicating a higher $\alpha$-amylase concentration.
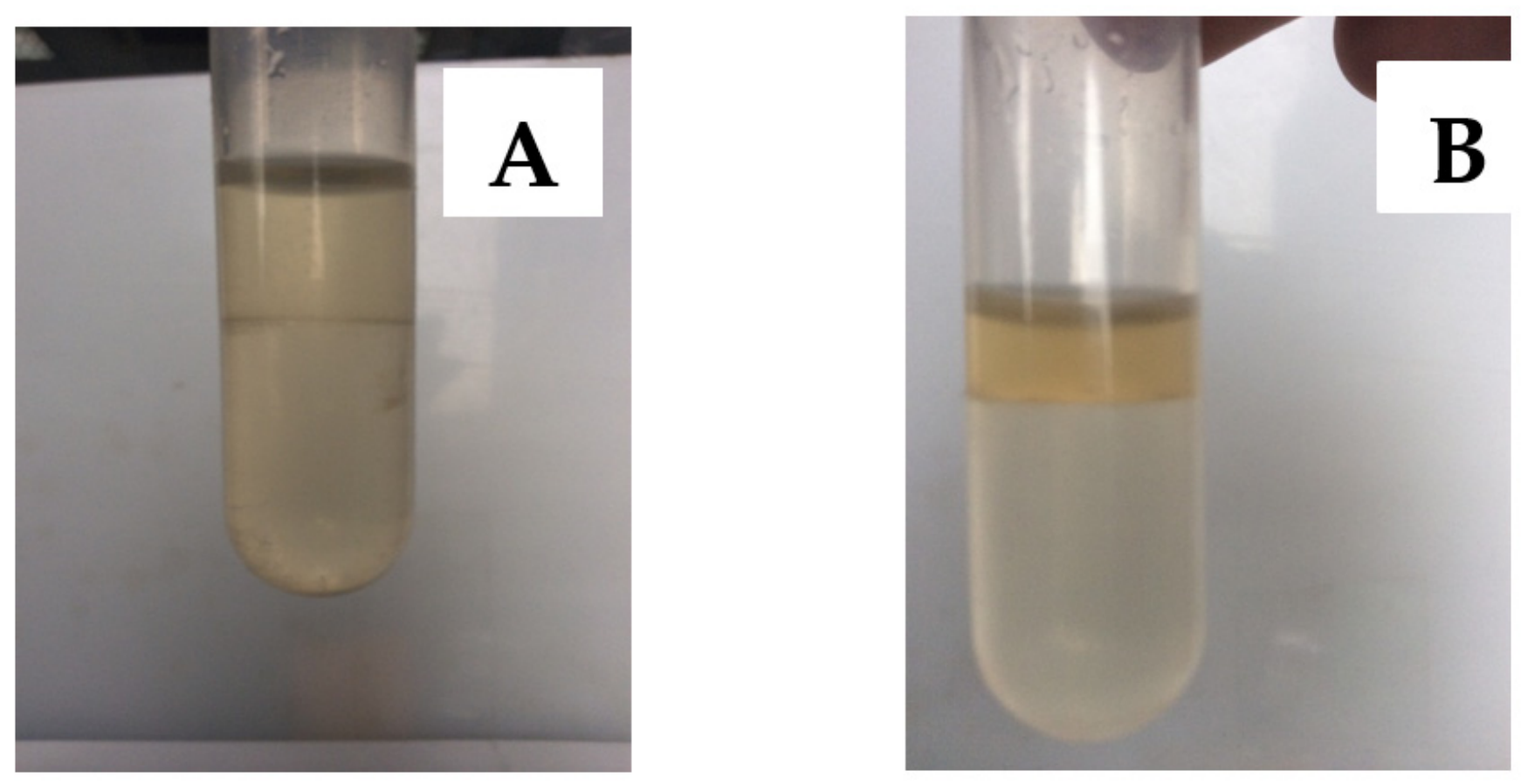

Figure 1. Images of different aqueous two-phase systems with $\alpha$-amylase. (A) Formulation 2, the PEG/phosphate system. (B) Formulation 4, the PEG/sulfate system. The upper phase was PEG, the lower phase was salt.

\subsection{Characterization of Porous Microscaffolds}

The porous microscaffolds were prepared by the water-in-oil-in-water $\left(\mathrm{W}_{1} / \mathrm{O} / \mathrm{W}_{2}\right)$ solvent evaporation method, using $\mathrm{NH}_{4} \mathrm{HCO}_{3}$ as a gas-producing agent. The porosity could be adjusted by the proportion of $\mathrm{NH}_{4} \mathrm{HCO}_{3}$, and partly by the PEG because of its leaching process. Neither a too low nor a too high porosity was desired, as a low porosity might limit the protein drug loading capacity and a high porosity might make the pore-closing process difficult $[29,30]$.

The amount of $\mathrm{NH}_{4} \mathrm{HCO}_{3}$ was differed in formulations of microscaffolds, at a percentage of $10 \%, 15 \%$, and $20 \%$. According to the SEM images, formulations were roughly selected by the size of the pores and porosity. The porosity and pore size increased directly with the increase amount of $\mathrm{NH}_{4} \mathrm{HCO}_{3}$. Figure $2 \mathrm{~A}, \mathrm{~B}$ is the microscaffolds with $20 \%$ and $15 \% \mathrm{NH}_{4} \mathrm{HCO}_{3}$. Such a highly porous structure might impede the pore-closing process, 
which was based on the mobility of the polymer. Figure $2 \mathrm{C}$ shows the formulation with $10 \% \mathrm{NH}_{4} \mathrm{HCO}_{3}$, only small pores were found on the surface due to the lower amount of $\mathrm{NH}_{4} \mathrm{HCO}_{3}$. Figure 2D is an amplified image of Figure 2c. Given that the protein drug was loaded in the solution state, such a pore size was big enough for loading and could facilitate the pore-closing process. Figure 2E,F is the pore-closed microscaffolds heated above the $\mathrm{Tg}$ for $24 \mathrm{~h}$. It was clear that the pores were closed successfully and could be used as a sustained depot. Otherwise, the pores would lead to a severe initial burst and a much shorter release period. Figure $2 \mathrm{G}$ shows a sectional view of pore-closed microscaffolds. Even though the pores on the surface were closed, the inner porous structure did not disappear completely. Compared with similar studies [21], it was found that the addition of PEG during the microscaffold hardening could inhibit the pore-forming process, resulting in a reduction of porous structure, most probably because PEG enhanced the mobility of polymeric chains of PLGA, and self-encapsulation also happened in the hardening process.
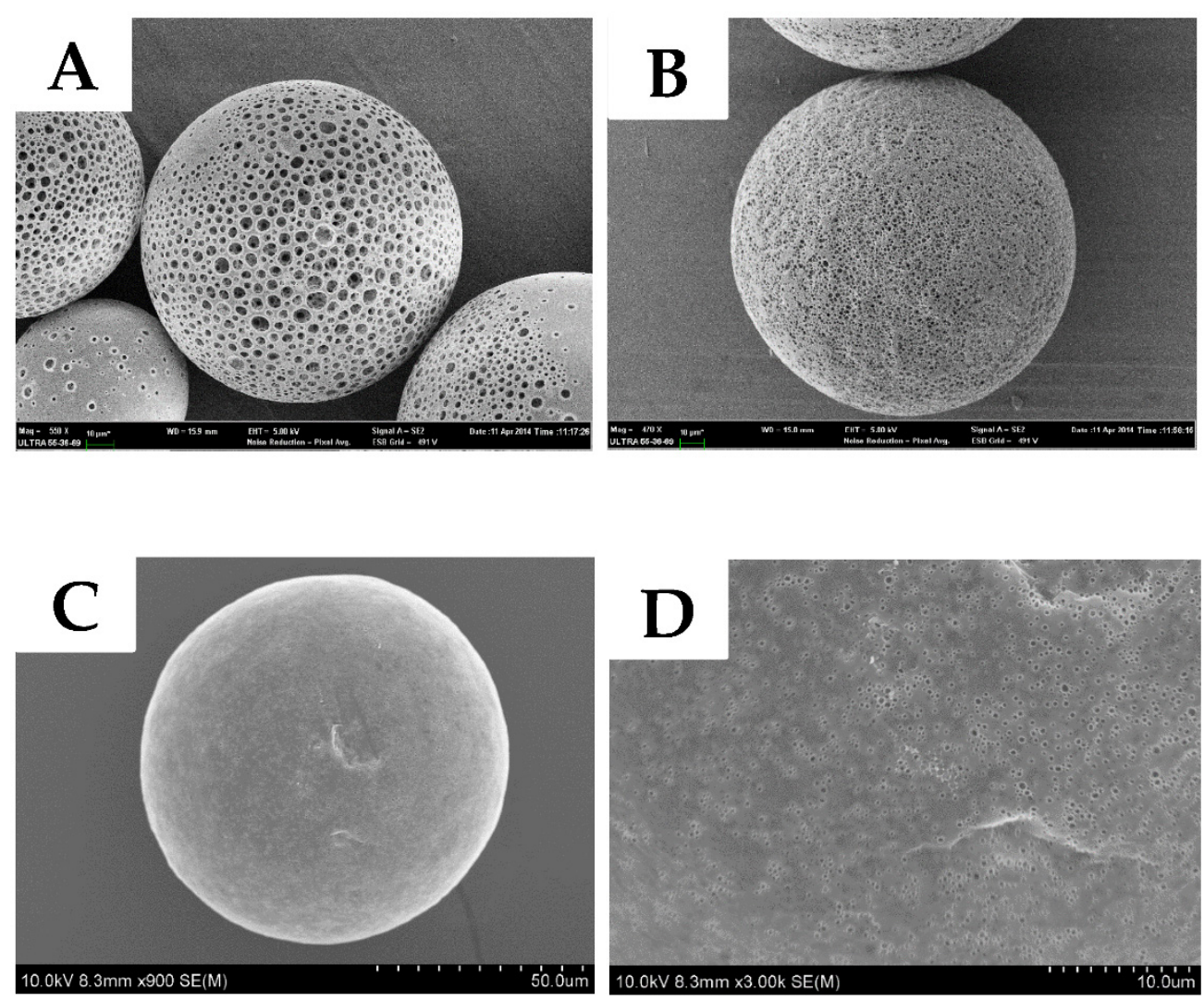

Figure 2. Cont. 

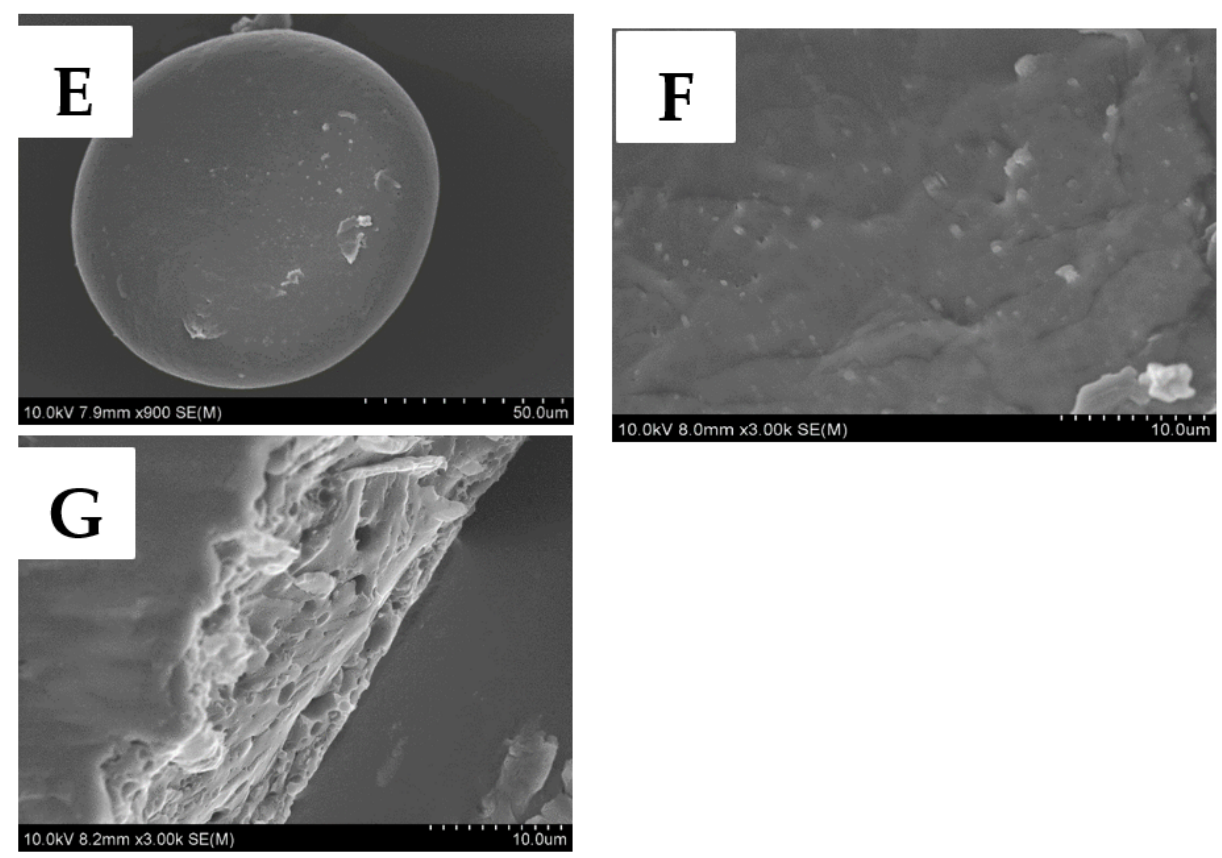

Figure 2. Scanning electron microscope images of different formulations. (A) Microscaffolds of $20 \% \mathrm{NH}_{4} \mathrm{HCO}_{3}$. (B) Microscaffolds of $15 \% \mathrm{NH}_{4} \mathrm{HCO}_{3}$. (C) Microscaffolds of $10 \% \mathrm{NH}_{4} \mathrm{HCO}_{3}$. (D) Amplified image of microscaffolds of $10 \% \mathrm{NH}_{4} \mathrm{HCO}_{3}$. (E) Pore-closed microscaffolds of $10 \%$ $\mathrm{NH}_{4} \mathrm{HCO}_{3}$. (F) Amplified image of pore-closed microscaffolds of $10 \% \mathrm{NH}_{4} \mathrm{HCO}_{3}$. (G) Sectional image of pore-closed microscaffolds of $10 \% \mathrm{NH}_{4} \mathrm{HCO}_{3}$.

Figure 3 shows that the surface weighted average particle size of microscaffolds was $96.84 \mu \mathrm{m}$, with a uniformity of 0.218 . Hence, it was not necessary to sieve before being used to eliminate the variation of different samples.

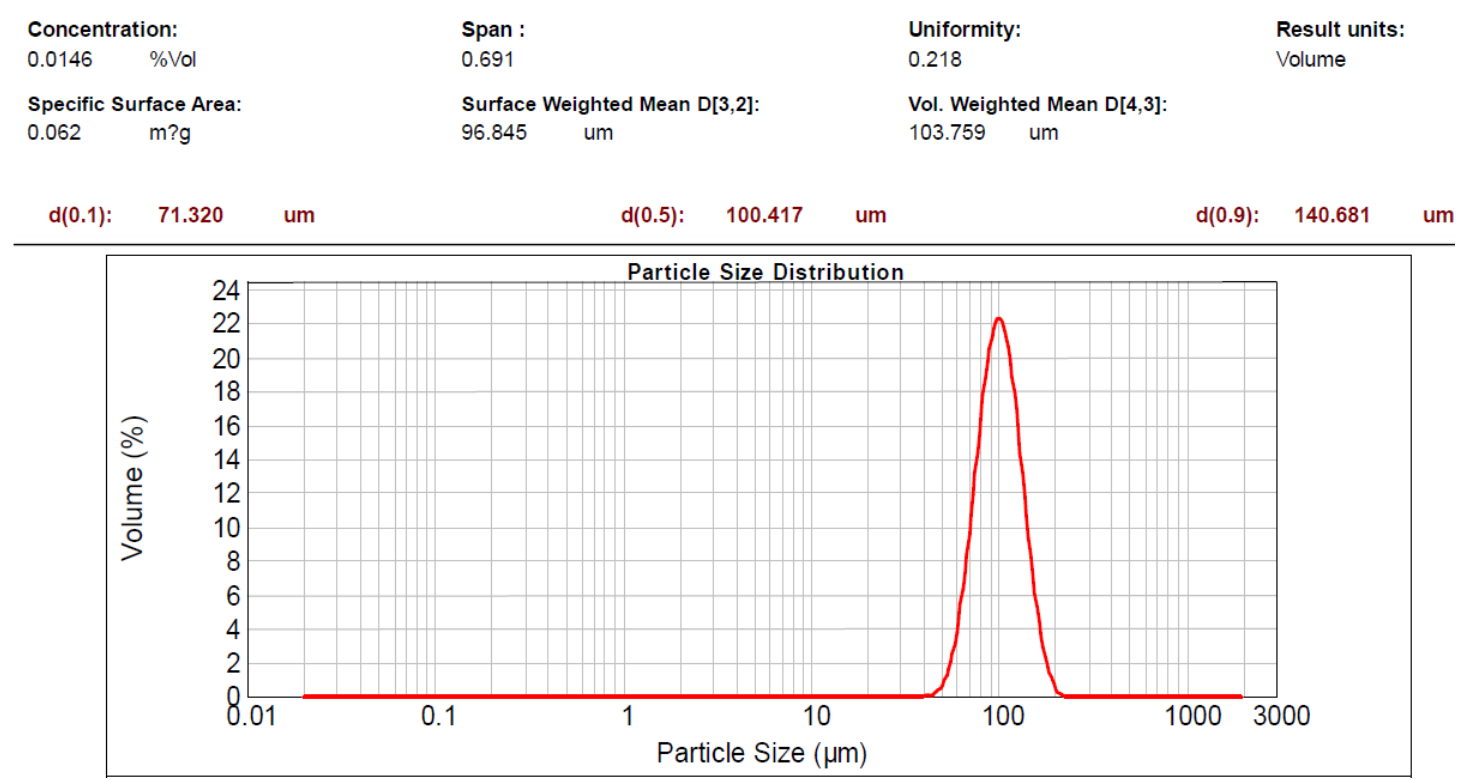

Figure 3. Size distribution of the porous microscaffolds. Formulation contained $10 \% \mathrm{NH}_{4} \mathrm{HCO}_{3}$.

Figure 4 shows that the glass transition temperature of porous microscaffolds was $39.27^{\circ} \mathrm{C}$. Thus, in the pore-closing process, the temperature was set at $42{ }^{\circ} \mathrm{C}$, slightly higher 
than the Tg to mobilize the polymeric chains to close the pores. The amount of PEG was found to have an influence on the $\mathrm{Tg}$.

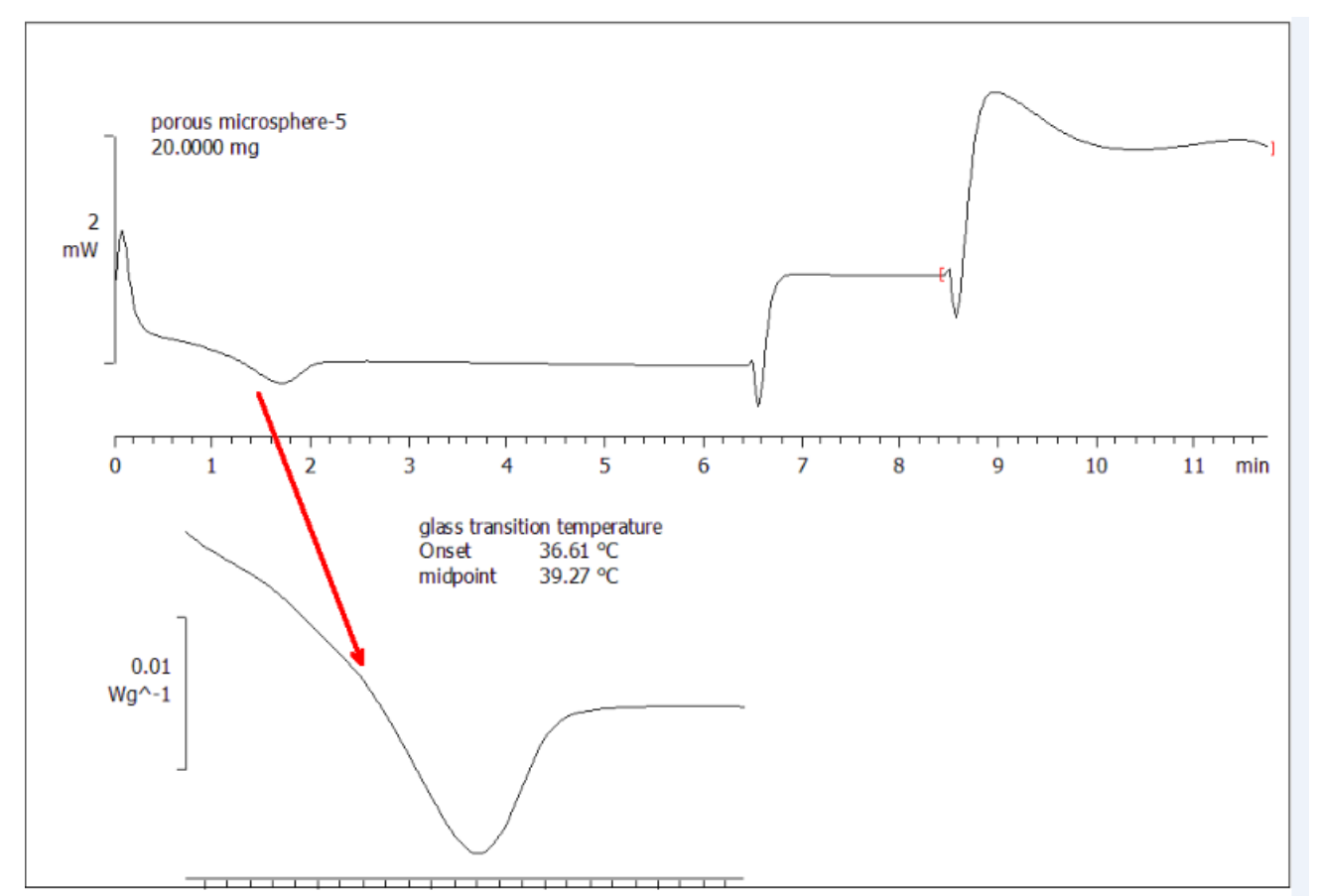

Figure 4. Differential scanning calorimeter thermogram of porous microscaffolds $\left(10 \% \mathrm{NH}_{4} \mathrm{HCO}_{3}\right)$. The temperature corresponding to the midpoint of the negative peak was the glass transition temperature.

\subsection{Determination of Loading Amount}

According to the mBET theory, the surface areas of blank microscaffolds and pore closed microscaffolds were about $0.998 \mathrm{~m}^{2} \mathrm{~g}^{-1}$ and $1.502 \mathrm{~m}^{2} \mathrm{~g}^{-1}$, respectively. BJH analysis showed that the average pore diameters on blank microscaffolds and pore closed microscaffolds were about $30.578 \mathrm{~nm}$ and $3.413 \mathrm{~nm}$, respectively. Therefore, in combination with the results in Figure 2, we know that compared with blank microscaffolds, some pores were closed in microscaffolds loaded with protein and the protein was successfully encapsulated in the microscaffolds. This result was consistent with the findings of Homayun, B. et al. [31].

The key issue of the porous microscaffolds is how to improve the loading amount to emulate the traditional microscaffolds. From Table 2, a high loading amount of $9.67 \pm 6.28 \%$ could be achieved by employing the aqueous two-phase system compared with the protein drug-only control group $(0.16 \pm 0.10 \%)$. The protein drug loading medium consisted of ammonium sulfate and PEG had a lower loading amount than that of the one of ammonium sulfate-only. This could be attributed to the protein drug being able to stay in the PEG phase out of the microscaffolds rather than get into the pores. On the other hand, formulation 2 , which had sulfate only, could force the protein drug to enter the porous structure and stay with the PEG pre-encapsulated in microscaffolds. Formulation 3 with no PEG preencapsulated in the microscaffolds showed a much lower loading amount, indicating the necessary presence of PEG. 
Table 2. The loading amount of $\alpha$-amylase in different formulations. The ammonium sulfate and PEG4000 were the composition of the protein drug loading medium. Microscaffolds were suspended and violently shaken in the medium for $24 \mathrm{~h}$. All data are presented as mean $\pm S D, n=3$.

\begin{tabular}{ccccc}
\hline Formulation & $\begin{array}{c}\text { Ammonium } \\
\text { Sulfate }(w / v)\end{array}$ & PEG4000 (w/v) & Microscaffolds & $\begin{array}{c}\text { Loading } \\
\text { Amount }(w / w)\end{array}$ \\
\hline 1 & $20 \%$ & $10 \%$ & PEG & $1.67 \pm 0.23 \%$ \\
2 & $20 \%$ & 0 & PEG & $9.67 \pm 6.28 \%$ \\
3 & $20 \%$ & 0 & NO PEG & $1.21 \pm 0.52 \%$ \\
4 & 0 & 0 & PEG & $0.16 \pm 0.10 \%$ \\
\hline
\end{tabular}

Furthermore, not only $\alpha$-amylase can have a high loading amount in PLGA microscaffolds. Any other hydrophobic protein drugs also have the potential to have a high partition coefficient in PEG phase and can be encapsulated in microscaffolds such as lysozyme, thaumatin, and conalbumin [32-34]. A PEG-PLGA copolymer has been synthesized and applied already $[35,36]$ and may have better performance because PEG chains were fixed in porous microscaffolds, unlikely to diffuse into the outer sulfate phase.

\subsection{Release In Vitro}

Figure 5 shows the cumulative release curve of both pore-closed microscaffolds and the porous microscaffolds. The initial burst of porous particles was severe, with more than $60 \%$ released in the first two days, making it unsuitable for sustained release. The unclosed pores became the channels for water, which not only promoted the release of thee protein drug, but also accelerated the degradation of PLGA microscaffolds. The higher cumulative release rate at 14 days could also verify the faster degradation in porous microscaffolds. In contrast, the release profile of pore-closed microscaffolds was more stable. The results were consistent with previous studies of Kang, J. et al. [15]. Generally, PLGA 2A (MW:12000) is used for 1-month sustained release use. Thus, the uncompleted release was normal and the remained protein drug was assayed by dissolving the PLGA with acetonitrile.

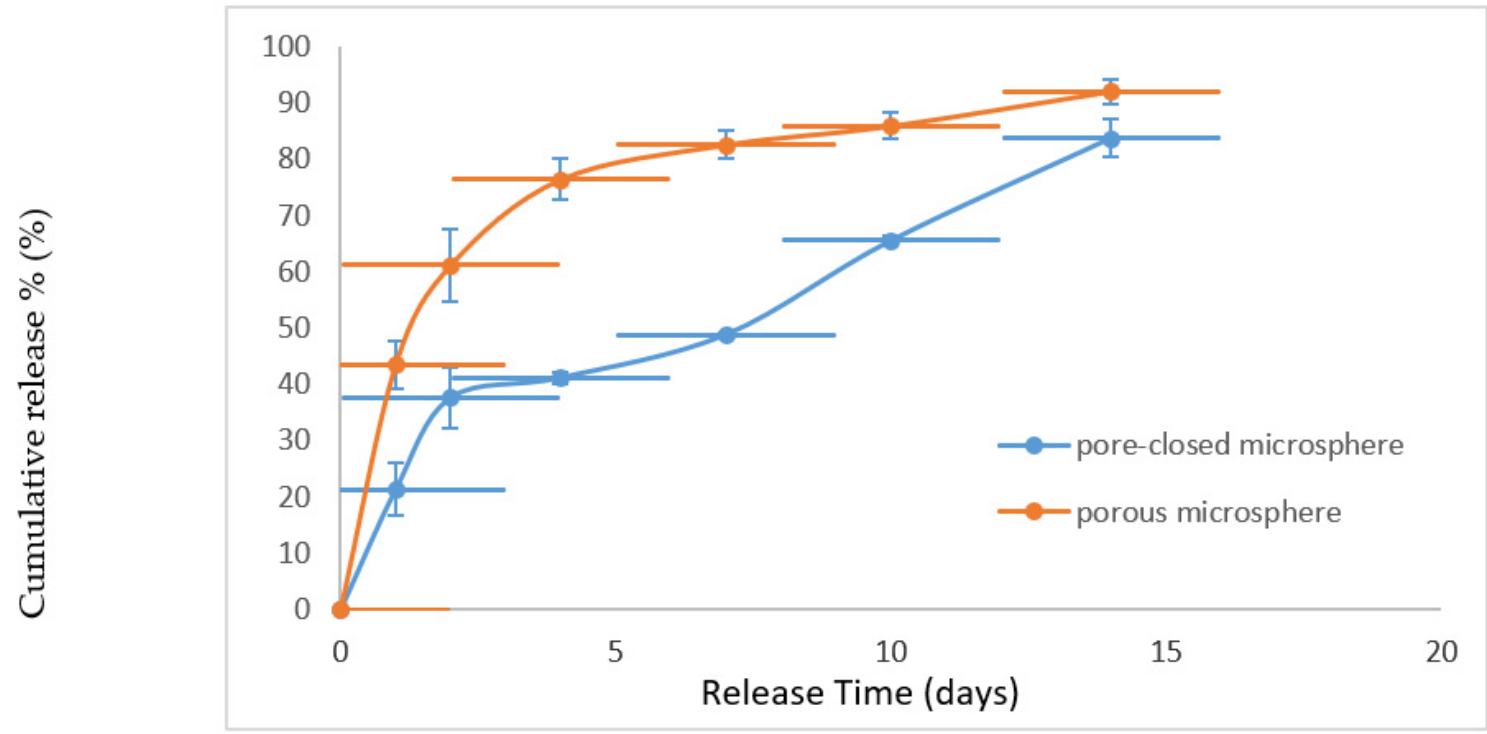

Figure 5. Cumulative release curve of $\alpha$-amylase. Porous microscaffolds and pore-closed microscaffolds were compared. All data are presented as mean $\pm \mathrm{SD}, \mathrm{n}=3$.

\subsection{Size Exclusion Chromatography}

The chromatography showed a similar retention time of native and released $\alpha$-amylase. As shown in Figure 6, the native $\alpha$-amylase had a relatively wide tailing peak, indicating it 
was a mixture of slightly aggregated $\alpha$-amylase and monomer. After loading and releasing, the released $\alpha$-amylase showed a sharp peak, which shared the same retention time of the aggregated part of $\alpha$-amylase.
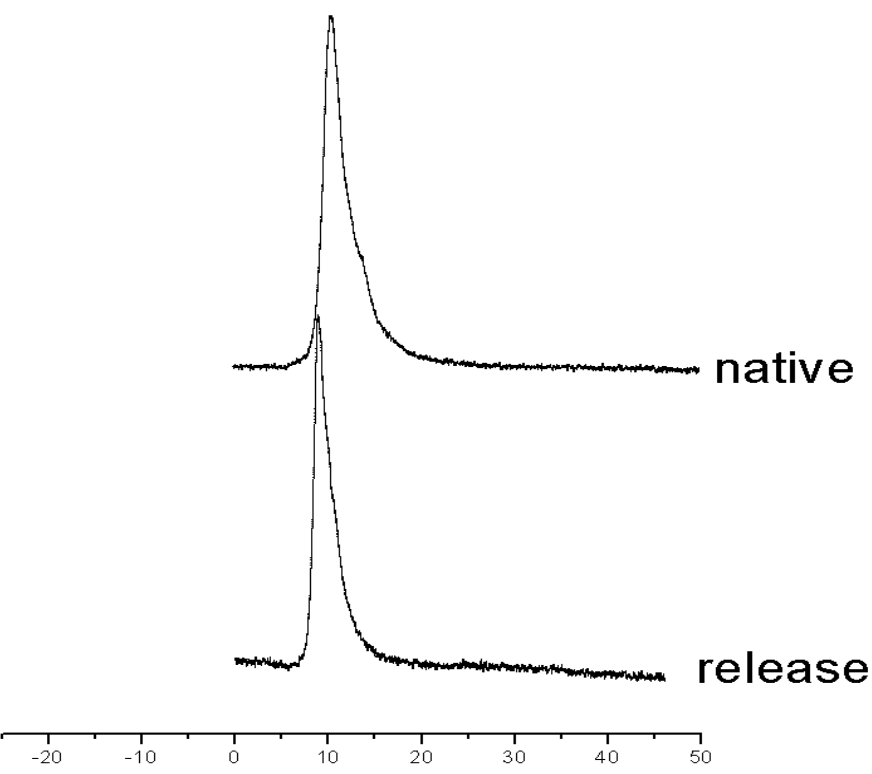

Figure 6. Size exclusion chromatography. The "release" was sample released from pore-closed microscaffolds after one day and the "native" was native $\alpha$-amylase diluted into a concentration about $0.2 \mathrm{mg} / \mathrm{mL}$.

In order to explore whether the structure of the protein encapsulated by the microscaffolds changed during the preparation process, we carried out circular CD spectra on the untreated $\alpha$-amylase and $\alpha$-amylase released from pore-closed microscaffolds. Figure 7 showed the far-UV CD spectra of native $\alpha$-amylase and $\alpha$-amylase released from poreclosed microscaffolds. The conformational state of released $\alpha$-amylase was not changed from that of native $\alpha$-amylase. This indicates that the encapsulation of $\alpha$-amylase in microscaffolds does not impair its natural conformational state or function. This finding is consistent with previous reports by Paik, D.H. et al., who encapsulated BSA in porous PLGA microspheres, and the encapsulated BSA retained its specific bioactivity [37].

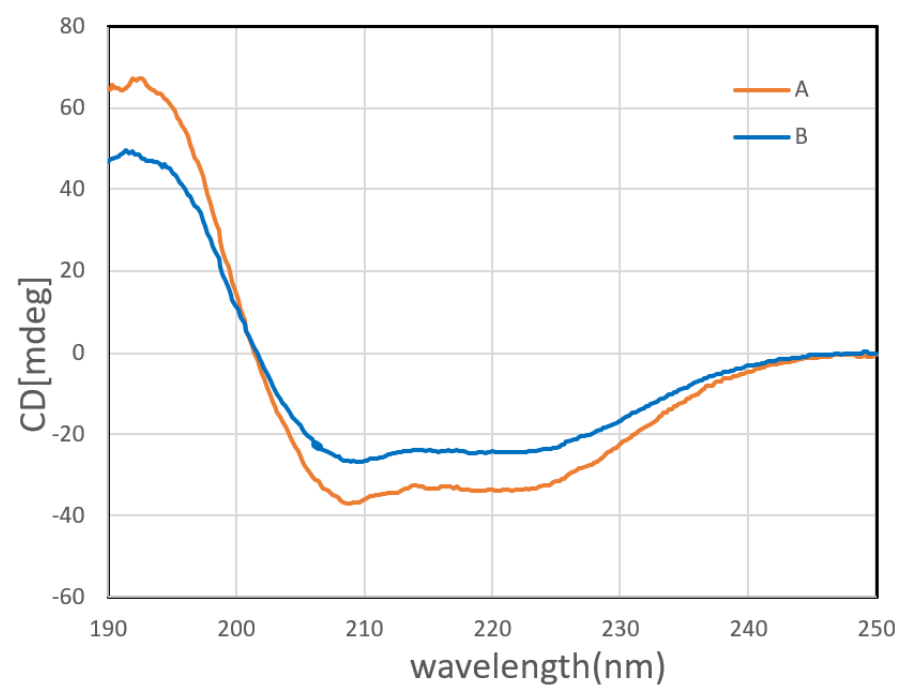

Figure 7. Circular dichroism spectra of (A) native $\alpha$-amylase and (B) $\alpha$-amylase released from pore-closed microscaffolds. 


\subsection{Activity of $\alpha$-Amylase}

The activity was measured by the DNS reagent, based on the reducing sugar produced in its reaction with starch. Relative activity was calculated and the activity of native $\alpha$-amylase was set as 1 . The testing sample was the $\alpha$-amylase released one day from microscaffolds. The absorbance was converted into the concentration of reducing sugar first, according to the standard curve made by glucose. The amount of protein drug was measured using the BCA method.

From Figure 8 , the released $\alpha$-amylase showed a high relative activity, demonstrating that the preparation method was mild and friendly to $\alpha$-amylase. Theoretically, the aqueous two-phase system is mild and has been successfully applied to extract and separate protein drugs for decades. Thus, the key factor that may alter the activity of protein drug is the pore-closing process, which is performed at a relatively high temperature (above $\mathrm{Tg}$ ), usually 30 to $50^{\circ} \mathrm{C}$ for PLGA. The $\alpha$-amylase we used here was a thermostable one, which had an optimum temperature of 60 to $70^{\circ} \mathrm{C}$. Other extremely heat-sensitive protein drugs could be damaged by this pore-closing method. In this case, the pore-closing process needs to be performed at a lower temperature with substances that can facilitate the mobility of polymeric chains, for example, PEG.

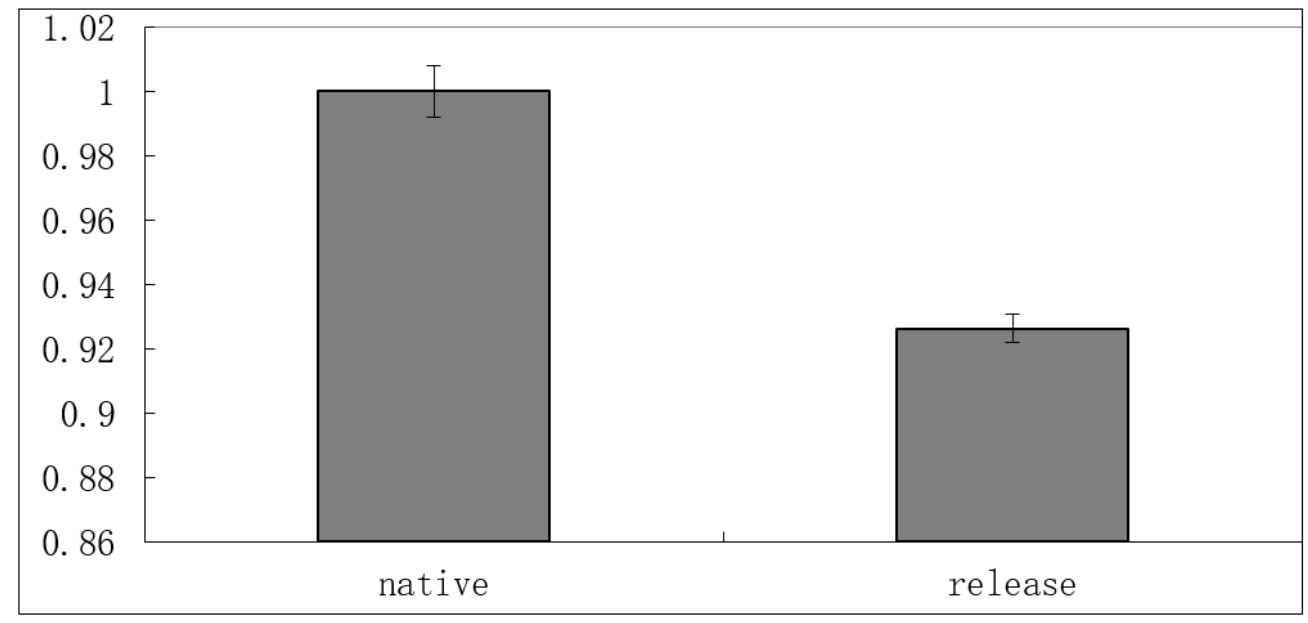

Figure 8. Relative activity of released $\alpha$-amylase. All data are presented as mean $\pm S D, n=3$.

\section{Conclusions}

A novel method, encapsulating $\alpha$-amylase effectively and stably into PLGA microscaffolds was proposed with the application of an aqueous two-phase system. Selfencapsulating microscaffolds increased protein drug loading and promoted the sustained release of encapsulated proteins. The sulfate/PEG system was friendly to protein drugs, avoiding any organic solvent, high temperature, or violent mechanical force used in traditional preparation methods. Protein drugs like $\alpha$-amylase have the potential to be encapsulated in microscaffolds once it has a high partition coefficient in the PEG/sulfate system. Further efforts are under way to investigate more ATPSs and protein drugs. A PEG-PLGA copolymer may have the potential to simplify this method and have a higher efficiency.

Author Contributions: W.-E.Y. conceived the conceptualization and conceived the study design, J.K., Y.C., Z.W. and S.W. participated in data extraction and analysis. J.K., Y.C., Z.W. and S.W. searched the databases and performed studies. J.K. and Y.C. drafted the manuscript. W.-E.Y. revised the manuscript. All authors have read and agreed to the published version of the manuscript.

Funding: The study was supported by the Interdisciplinary Program of Shanghai Jiao Tong University (No. ZH2018QNA56).

Institutional Review Board Statement: Not applicable. 
Informed Consent Statement: Not applicable.

Data Availability Statement: Not applicable.

Acknowledgments: We appreciate the help from the Faculties of Instrumental Analysis Center (IAC) of Shanghai Jiao Tong University and the support from the Base for Interdisciplinary Innovative Talent Training.

Conflicts of Interest: The authors declare no conflict of interest.

\section{References}

1. Zhang, B.J.; Han, Z.W.; Duan, K.; Mu, Y.D.; Weng, J. Multilayered pore-closed PLGA microsphere delivering OGP and BMP-2 in sequential release patterns for the facilitation of BMSCs osteogenic differentiation. J. Biomed. Mater. Res. A 2018, 106, 95-105. [CrossRef]

2. Sinha, V.; Trehan, A. Biodegradable microspheres for protein delivery. J. Control. Release 2003, 90, 261-280. [CrossRef]

3. Wei, Z.; Volkova, E.; Blatchley, M.R.; Gerecht, S. Hydrogel vehicles for sequential delivery of protein drugs to promote vascular regeneration. Adv. Drug Deliv. Rev. 2019, 149-150, 95-106. [CrossRef]

4. Varanko, A.; Saha, S.; Chilkoti, A. Recent trends in protein and peptide-based biomaterials for advanced drug delivery. Adv. Drug Deliv. Rev. 2020, 156, 133-187. [CrossRef] [PubMed]

5. Kip, C.; Tosun, R.B.; Alpaslan, S.; Kocer, I.; Celik, E.; Tuncel, A. Ni(II)-decorated porous titania microspheres as a stationary phase for column chromatography applications: Highly selective purification of hemoglobin from human blood. Talanta 2019, 200, 100-106. [CrossRef] [PubMed]

6. Whitely, M.; Rodriguez-Rivera, G.; Waldron, C.; Mohiuddin, S.; Cereceres, S.; Sears, N.; Ray, N.; Cosgriff-Hernandez, E. Porous PolyHIPE microspheres for protein delivery from an injectable bone graft. Acta Biomater. 2019, 93, 169-179. [CrossRef] [PubMed]

7. Reinhold, S.E.; Desai, K.G.H.; Zhang, L.; Olsen, K.F.; Schwendeman, S.P. Self-Healing Microencapsulation of Biomacromolecules without Organic Solvents. Angew. Chem. Int. Ed. 2012, 51, 10800-10803. [CrossRef] [PubMed]

8. Desai, K.-G.H.; Schwendeman, S.P. Active self-healing encapsulation of vaccine antigens in PLGA microspheres. J. Control. Release 2013, 165, 62-74. [CrossRef] [PubMed]

9. Kim, H.K.; Chung, H.J.; Park, T.G. Biodegradable polymeric microspheres with "open/closed" pores for sustained release of human growth hormone. J. Control. Release 2006, 112, 167-174. [CrossRef] [PubMed]

10. He, C.; Li, S.; Liu, H.; Li, K.; Liu, F. Extraction of testosterone and epitestosterone in human urine using aqueous two-phase systems of ionic liquid and salt. J Chromatogr. A 2005, 1082, 143-149. [CrossRef]

11. Balasubramaniam, D.; Wilkinson, C.; Van Cott, K.; Zhang, C. Tobacco protein separation by aqueous two-phase extraction. J. Chromatogr. A 2003, 989, 119-129. [CrossRef]

12. Iqbal, M.; Tao, Y.; Xie, S.; Zhu, Y.; Chen, D.; Wang, X.; Huang, L.; Peng, D.; Sattar, A.; Shabbir, M.A.; et al. Aqueous two-phase system (ATPS): An overview and advances in its applications. Biol. Proced. Online 2016, 18, 18. [CrossRef] [PubMed]

13. Seo, H.; Nam, C.; Kim, E.; Son, J.; Lee, H. Aqueous Two-Phase System (ATPS)-Based Polymersomes for Particle Isolation and Separation. ACS Appl. Mater. Interfaces 2020, 12, 55467-55475. [CrossRef]

14. Shibata, C.; Iwashita, K.; Shiraki, K. Salt-containing aqueous two-phase system shows predictable partition of proteins with surface amino acids residues. Int. J. Biol. Macromol. 2019, 133, 1182-1186. [CrossRef]

15. Kang, J.; Schwendeman, S.P. Pore closing and opening in biodegradable polymers and their effect on the controlled release of proteins. Mol. Pharm. 2007, 4, 104-118. [CrossRef]

16. Asenjo, J.A.; Andrews, B.A. Aqueous two-phase systems for protein separation: A perspective. J. Chromatogr. A 2011, 1218, 8826-8835. [CrossRef] [PubMed]

17. Ahn, M.; Park, S.; Jeon, J.; Choi, J.K.; Khang, Y. Application of an S-layer protein as a self-aggregating tag for cost-effective separation of recombinant human and yeast D-amino acid oxidases in the aqueous two-phase system. Biotechnol. Lett. 2020, 42, 241-248. [CrossRef]

18. Assis, R.C.; Mageste, A.B.; de Lemos, L.R.; Orlando, R.M.; Rodrigues, G.D. Application of aqueous two-phase system for selective extraction and clean-up of emerging contaminants from aqueous matrices. Talanta 2021, 223, 121697. [CrossRef]

19. Akamatsu, K.; Kurita, R.; Sato, D.; Nakao, S.I. Aqueous Two-Phase System Formation in Small Droplets by Shirasu Porous Glass Membrane Emulsification Followed by Water Extraction. Langmuir 2019, 35, 9825-9830. [CrossRef]

20. Li, J.; Zhao, Y.; Jiang, X. Quantitative analysis of protein in thermosensitive hydroxypropyl chitin for biomedical applications. Anal. Biochem. 2020, 599, 113745. [CrossRef] [PubMed]

21. Kim, T.K.; Yoon, J.J.; Lee, D.S.; Park, T.G. Gas foamed open porous biodegradable polymeric microspheres. Biomaterials 2006, 27, 152-159. [CrossRef]

22. Thommes, M.; Kaneko, K.; Neimark, A.V.; Olivier, J.P.; Rodriguez-Reinoso, F.; Rouquerol, J.; Sing, K.S.W. Physisorption of gases, with special reference to the evaluation of surface area and pore size distribution (IUPAC Technical Report). Pure Appl. Chem. 2015, 87, 1051-1069. [CrossRef]

23. Lee, J.; Choi, Y.C. Pore Structure Characteristics of Foam Composite with Active Carbon. Materials 2020, 13, 4038. [CrossRef]

24. Ghose, T. Measurement of cellulase activities. Pure Appl. Chem. 1987, 59, 257-268. [CrossRef] 
25. Farooq, M.A.; Ali, S.; Hassan, A.; Tahir, H.M.; Mumtaz, S.; Mumtaz, S. Biosynthesis and industrial applications of $\alpha$-amylase: A review. Arch. Microbiol. 2021. [CrossRef]

26. Gündüz, U.; Korkmaz, K. Bovine serum albumin partitioning in an aqueous two-phase system: Effect of pH and sodium chloride concentration. J. Chromatogr. B Biomed. Sci. Appl. 2000, 743, 255-258. [CrossRef]

27. Wang, Z.; Chen, X.; Wan, J.; Cao, X. Study of Microbial Transglutaminase Partitioning in Thermo-pH-Responsive Aqueous Two-Phase Systems. Appl. Biochem. Biotechnol. 2020, 192, 1176-1190. [CrossRef] [PubMed]

28. Amaral, Y.M.S.; da Silva, O.S.; de Oliveira, R.L.; Porto, T.S. Production, extraction, and thermodynamics protease partitioning from Aspergillus tamarii Kita UCP1279 using PEG/sodium citrate aqueous two-phase systems. Prep. Biochem. Biotechnol. 2020, 50, 619-626. [CrossRef]

29. Sediq, A.S.; Waasdorp, S.K.D.; Nejadnik, M.R.; van Beers, M.M.C.; Meulenaar, J.; Verrijk, R.; Jiskoot, W. A Flow Imaging Microscopy-Based Method Using Mass-to-Volume Ratio to Derive the Porosity of PLGA Microparticles. J. Pharm. Sci. 2017, 106, 3378-3384. [CrossRef] [PubMed]

30. Zhang, X.; Qin, L.; Su, J.; Sun, Y.; Zhang, L.; Li, J.; Beck-Broichsitter, M.; Muenster, U.; Chen, L.; Mao, S. Engineering large porous microparticles with tailored porosity and sustained drug release behavior for inhalation. Eur. J. Pharm. Biopharm. 2020, 155, 139-146. [CrossRef] [PubMed]

31. Homayun, B.; Choi, H.J. Halloysite nanotube-embedded microparticles for intestine-targeted co-delivery of biopharmaceuticals. Int. J. Pharm. 2020, 579, 119152. [CrossRef] [PubMed]

32. Hachem, F.; Andrews, B.; Asenjo, J. Hydrophobic partitioning of proteins in aqueous two-phase systems. Enzym. Microb. Technol. 1996, 19, 507-517. [CrossRef]

33. Asenjo, J.; Schmidt, A.; Hachem, F.; Andrews, B. Model for predicting the partition behaviour of proteins in aqueous two-phase systems. J. Chromatogr. A 1994, 668, 47-54. [CrossRef]

34. Cascone, O.; Andrews, B.; Asenjo, J. Partitioning and purification of thaumatin in aqueous two-phase systems. Enzym. Microb. Technol. 1991, 13, 629-635. [CrossRef]

35. Beletsi, A.; Panagi, Z.; Avgoustakis, K. Biodistribution properties of nanoparticles based on mixtures of PLGA with PLGA-PEG diblock copolymers. Int. J. Pharm. 2005, 298, 233-241. [CrossRef] [PubMed]

36. Kim, H.K.; Park, T.G. Surface Stabilization of Diblock PEG-PLGA Micelles by Polymerization of N-Vinyl-2-pyrrolidone. Macromol. Rapid Commun. 2002, 23, 26-31. [CrossRef]

37. Paik, D.H.; Choi, S.W. Entrapment of protein using electrosprayed poly(D,L-lactide-co-glycolide) microspheres with a porous structure for sustained release. Macromol. Rapid Commun. 2014, 35, 1033-1038. [CrossRef] [PubMed] 